\title{
連載
}

\section{講 義}

\section{海水中におけるステンレス鋼の} 微生物腐食*

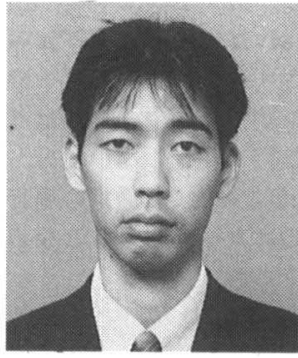

天 谷尚

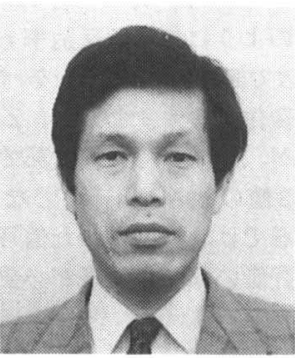

幸英 昭

天 谷尚**，幸

英 昭***

Microbially Influenced Corrosion on Stainless Steels in Natural Seawater*

by Hisashi Amaya** and Hideaki Miyuki***

キーワード : 微生物腐食, ステンレス鋼, 海水, バクテリ ア, 腐食電位, メカニスム

\section{1. 緒}

金属材料を自然環境中で使用する際，微生物によ る影響を受け腐食を発生する場合があり，いわゆる 微生物腐食 (MIC; Microbially Influenced Corrosion) として認識されるようになった. 実際, MIC は 欧米を中心に, 各種プラントで発生していることが 報告され1-5)，多くの研究がなされている。例えば, 嫌気性環境下における鉄鋼材料の腐食に及ほす硫酸 塩還元菌の影響の研究 ${ }^{6-9)}$ は多く,また最近では好気 性環境下における一般細菌によるステンレス鋼の腐 食への影響 ${ }^{10)}$ が注目されている.特に, 自然海水中て の付着微生物の影響によるステンレス鋼の局部腐食 感受性の増大が知られており, この分野ての研究が 近年, 活発化している.

そこで本報では，自然海水中におけるステンレス 鋼の腐食に及ぽす微生物の影響について, 現在まて の解明点を中心に紹介したい.

\section{2. 自然海水中におけるステンレス鋼の腐食挙動}

自然海水中ではステンレス鋼の孔食, すきま腐食

\footnotetext{
"原稿受付 平成 6 年 11 月 30 日

**正員 住友金属工業䊝 Member, Sumitomo Metal Industries, Ltd.
}

等の局部腐食感受性が人工海水中に比へて高く, そ の腐食性が著しく厳しいことが知られている ${ }^{11)}$ 。こ の局部腐食感受性の増大の原因として, 自然海水中 ての腐食電位（Ecorr）の貴化現象が指摘されてい る12).すなわち, 自然海水中ではステンレス鋼の Ecorr が次第に上昇し, 孔食電位あるいはすきま腐 食発生電位を越えた場合, 局部腐食の発生に至るも

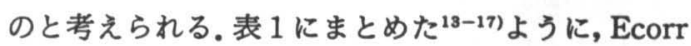
の貴化は, $+200 〜+400$ mv vs. SCE の範囲で, 海域 によらずほほ一定で, 普遍的な現象である.

また，図 1 に示すように，人工海水中ての Ecorr はほほ一定で貴化現象が認められず, 減菌海水中 ${ }^{17)}$ や滤過海水中帛)でも同様に貴化せず,ささらに, 殺菌作

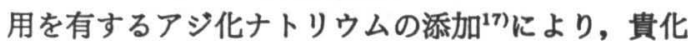
した状態から Ecorr が低下したことからも Ecorr の貴化は自然海水中に存在している微生物の影響と 考えられる.また, Ecorr の貴化したステンレス鋼試 験片のカソード分極曲線を測定した例ては, 貴な電

表 1 自然海水中での Ecorr の貴化現象の測定例

\begin{tabular}{c|c|c}
\hline \hline Stainless steel & Ecorr mV SCE & Reference No. \\
\hline Type 316 & +195 & $13)$ [U.S.A.] \\
\hline $254 \mathrm{SMO}$ & +300 & $14)$ [Norway] \\
\hline $26 \mathrm{Cr}-23 \mathrm{Ni}-4 \mathrm{Mo}$ & +400 & $15)$ [Japan] \\
\hline $904 \mathrm{~L}$ & +200 & $16)$ [Canada] \\
\hline $21 \mathrm{Cr}-3 \mathrm{Mo}$ & +350 & $17)[$ Italy] \\
\hline
\end{tabular}




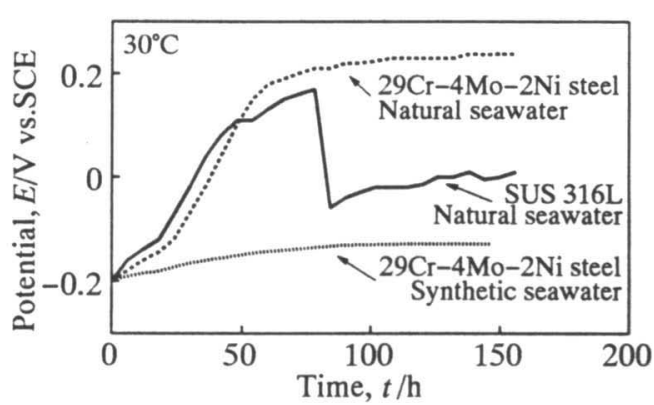

図1 自然海水および人工海水中での Ecorr 変化

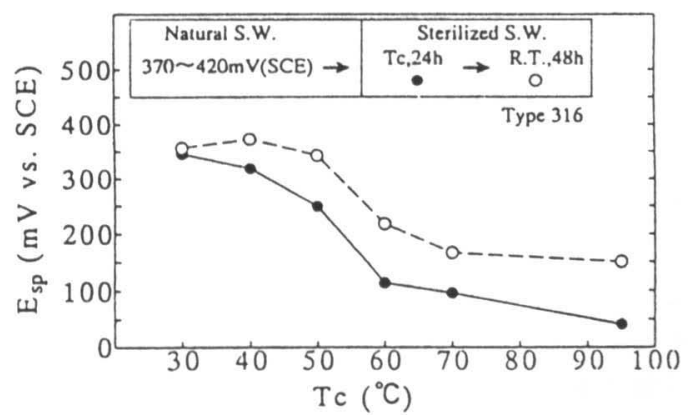

図 2 各種の温度 ( $\mathrm{Tc}$ ) の海水中 $24 \mathrm{~h}$ 浸漬がその後 の室温減菌海水中 $48 \mathrm{~h}$ 後の 316 鋼 Esp に及 ほすす影響（許可を得て転載）

位域で漫漬時間と比例したカソード電流の増大が見 られ ${ }^{18,19)}$, 付着微生物が還元反応に影響することが 指摘されている，また，日光の照射との関係を調へ た例では, Ecorr は昼間は貴で, 夜間または遮光され た条件下で卑となることが観察されている ${ }^{12)}$ 。この ことは, 夜間はパイオフィルム中の微生物の呼吸作 用により溶存酸素の濃度が低下し, 昼間は藻類の光 合成により溶存酸素が十分に供給されることと関係 があると考察されている.

また, 温度の影響についても検討されており, 自 然海水中において $+400 \mathrm{mV}$ vs. SCE 程度まで貴化 した 316 鋼を, 種々の温度の隇菌海水に 24 時間浸 漬させた後の Ecorr を測定した図 2 に示す例20)の ように, ほほ $50^{\circ} \mathrm{C}$ を境界に, 高温域での Ecorr の低 下が観測されている.これは, 高温では, 一般的に は微生物が生存し得ないので, Ecorr の貴化状態が 保持できなくなるためと考えられる.

\section{3. 付曾細菌を用いた再現試験}

自然海水中に漫漬した表面では種々の微生物から なるバイオフィルムが形成される.このバイオフィ ルム中の付着細菌を単離し, 実験室的に純粋培養し た系内におけるEcorrについても検討されてい

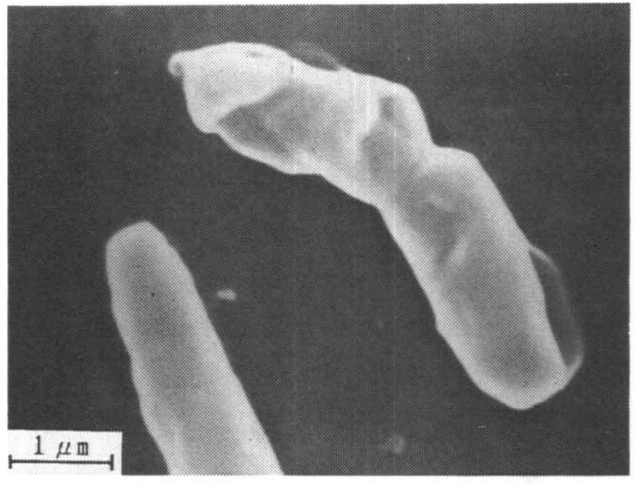

図 3 単離細菌の SEM 篗察写真

$ろ^{21,22)}$. 例えば図 3 に示した単離菌 (Pseudomonas $\mathrm{sp.)}$ を用いて細菌の増殖と Ecorr の変化を検討した

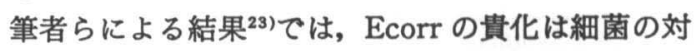
数增殖期と一致した. しかし, Ecorr は+10 mV vs. $\mathrm{SCE}$ 程度までしか貴化せず, 自然海水中でのレベル に比較してかなり卑であり,このような単離菌を用 いた試験では自然海水中でのレベルまで Ecorr の 貴化を再現することは容易ではない.

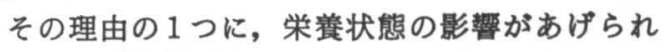
る. 自然海水は一般に賓栄養状態であり, 一方培屓 試験では, 自然海水に比較して富栄養な培地による バッチ式試験となる.そこで, 栄養状龍の違いによ る試験片表面への細菌の付着数について, 賓栄養培 地中では, 富栄養培地中よりも付着菌数が多くなる ことを確かめた. すなわち, 自然海水中ては, 蔶栄 養な状態の海水が連続的に供給され, 試験片表面に は細菌が付着しやすい状態であるのに対して, 純粋 培養による実験室的再現では富栄養培地によるパッ チ式であるために, 試験片表面での付着菌数が自然 海水中よりも少なく, Ecorr の貴化が難しくなるも のと考えられる.

\section{Ecorr 贵化現象のメカニスム}

付着微生物の作用による Ecorr の貴化現象に対 し, 従来考えられてきた原因には, 代謝産物の有機 酸による $\mathrm{pH}$ の低下 ${ }^{24)}$ や光合成による酸素濃度の増 大 ${ }^{15)}$ がある.ところが, $\mathrm{pH}$ や溶存酸素濃度のような 環境の変化が Ecorr に影響を与える場合,

$$
\begin{array}{ll}
\left(\mathrm{d} \mathrm{EO}_{2}\right) /(\mathrm{d} \mathrm{pH})_{02} & =-59 \mathrm{mV} \\
\left(\mathrm{d} \mathrm{EO}_{2}\right) /(\mathrm{d} \operatorname{logpO})_{\mathrm{pH}} & =+15 \mathrm{mV}
\end{array}
$$

となるが, 実際にはこれ以上に貴化することから, 単に $\mathrm{pH}$ や溶存酸素のみの変化では説明できないこ とが指摘されている ${ }^{25)}$. 


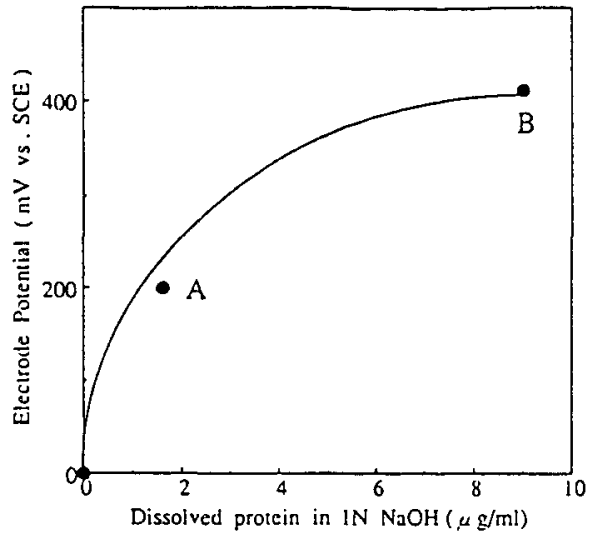

図 4 付着タンパク質量と Ecorr の関係（許可を得 て転載)

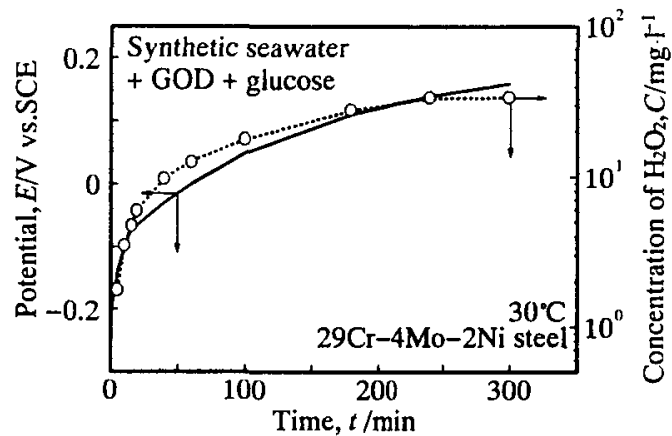

因 5 GOD 添加によるEcorrへの影豐と $\mathrm{H}_{2} \mathrm{O}_{2}$ の 生成

そこで最近，Ecorr 貴化に及ほすす他の因子の影響 も調べられている. 例えば，図 4 に示したように, 腐食電位と付着タンパク量とには相関のあることが 分かっている ${ }^{26)}$. また, 微量の過酸化水素が存在し $\mathrm{pH}$ が 3 以下でかつ溶存酸素濃度が低い条件下で Ecorr が貴化するとの報告もある27)。

筆者らは, Ecorr の貴化に細菌の代謝反応が関与 していることから，酸化酵素を人工海水に添加して 呼吸反応を模擬し，Ecorr に及沽す影響を検討した。 酸化酵素としてダルコースオキシダーゼ（GOD）を 使用し,あわせて基質であるグルコースを添加して, Ecorr 変化と䤃素反応に伴い生成する過酸化水素の 濃度変化を測定した。図 5 に示すように,Ecorr の貫 化と過酸化水素の生成挙動とには高い相関が見られ た，過酸化水素は,

$$
\mathrm{H}_{2} \mathrm{O}_{2}+2 \mathrm{H}^{+}+2 \mathrm{e}^{-} \rightarrow 2 \mathrm{H}_{2} \mathrm{O} \mathrm{E}^{0}=1.776 \mathrm{~V} \mathrm{SHE}
$$

のように酸素よりも非常に貴な酸化還元電位を有す るため，その存在下では，かなり高い Ecorr となり 得る.また実際, 自然海水中て生成したバイオフィ ルム中からわずかな過酸化水素が検出された。これ

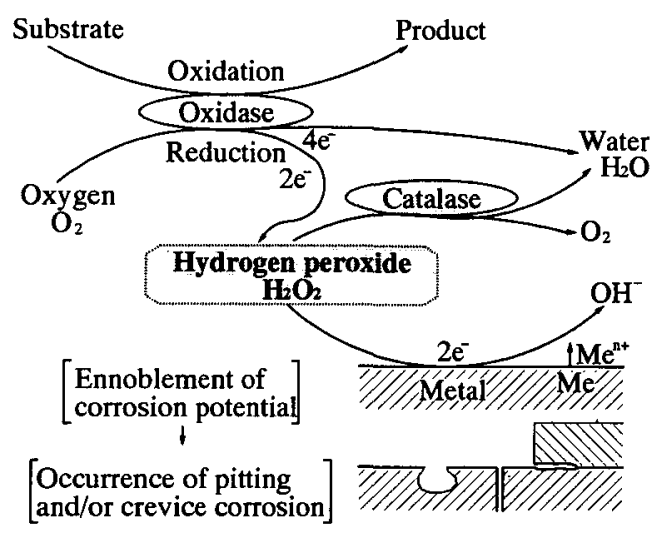

图 6 自然海水中に括けるステンレス鎆の MICメ カニスム

らの結果から，図6に示した自然海水中てのステン レス鋼の Ecorr 貴化のメカニスムを提示した ${ }^{28)}$.す なわち，ステンレス鋼表面に付着した細菌が代謝す る際に酸化醅素を生成して有機物を酸化する一方て 酸素の還元反応を触媒する．この反応の中間生成物 として過酸化水素などの活性酸素がバイオフィルム 内に蓄積されるが，過酸化水菜は生物体にとって有 客なためカタラーゼ等により分解される。しかし， その一部は直接ステンレス鋼表面においても反応 し, Ecorr が貴化する.これは, 細菌の呼吸反応の中 間体として生成する過酸化物 $\left(\mathrm{O}_{2}{ }^{2-}\right)$ あるいは超過 酸化物 $\left(\mathrm{O}_{2}{ }^{-}\right)$などの活性酸素種がステンレス鎆の腐 食に重大な影響を及沽す可能性を示唆するものであ ろ.

\section{5. 酸化醉来による再現試験法}

上述のように，ステンレス銅の MIC には細菌の 代謝反応が関与していることから，精製された酸化 醉素 (GOD) を用いて，細菌の呼吸反応を模擬する 人工的手法で Ecorr 貴化の再現を試みた ${ }^{29)}$.この酸 化酵素添加による MIC 再現試験法により，各種ス テンンス鋼のすきま腐食試験を行った結果，表 2 に 示すように，単なる人工海水浸清試験では同一条件 にもかかわらず再現が難しかった自然海水中ての腐 食挙動を，短期間に実験室的に再現できることが明

重 2 各種条件下にまけるすきま腐食試験結果比較

\begin{tabular}{c|c|c|c}
\hline \hline Steel & $\begin{array}{c}\text { Synthetic } \\
\text { seawater } \\
(180 \mathrm{~d})\end{array}$ & $\begin{array}{c}\text { Natural } \\
\text { seawater } \\
(180 \mathrm{~d})\end{array}$ & $\begin{array}{c}\text { GOD test } \\
(7 \mathrm{~d})\end{array}$ \\
\hline $316 \mathrm{~L}$ & $0 / 40$ & $16 / 40$ & $9 / 40$ \\
\hline 444 & $0 / 40$ & $6 / 40$ & $2 / 40$ \\
\hline $329 \mathrm{~J} 4 \mathrm{~L}$ & $0 / 40$ & $1 / 40$ & $1 / 40$ \\
\hline
\end{tabular}


らかになった，本試験法は実際の自然海水中の環境 をよくシミュレーションしており，従来の単離細菌 を用いた試験ては困難であった MIC の再現を，簡 便に実験室レべルで可能とするものである.

\section{6. おわりに}

本稿では，自然海水中におけるステンレス䤡の MIC の現状とメカニスムについて述べた. 海水中に おけるステンレス鋼の Ecorr の貴化は，地域によら ず普遍的にみられる現象であり，ステンレス鋼の耐 海水性を考える上で重要な問題である．その Ecorr 貴化の原因に対して，微生物の作用の観点からの研 究も活発となり，かなりメカニスムも明確になって きた. しかし, MIC は溶接部に発生しやすい30-32)な どの不明な点も多く，微生物によるバイオフィルム 形成の過程や生物間での相互作用の解明など, 微生 物学的側面からの詳細な検討もさらに重要性を增 し，今後より一層の研究が必要と考えられる.

\section{参考 女 献}

1) U. P. Sinha, J. H. Wolfram and R. D. Rogers: Micro bially Influenced Corrosion and Biodeterioration, Ed. by N. J. Dowling, M. W. Mittelman and J. C. Danko, NACE, 4-51 (1990).

2) J. W. Costerton and J. Boivin: Biological Fou. ling of Industrial Water Systems, Ed. by M. W. Mittelman and G. G. Geesey, Water Micro Associates, San Diego, 56 (1987).

3) G. Kobrin: Biologically Induced Corrosion, Ed. by S. C. Dexter, NACE, 33 (1986).

4) R. E. Tatnall: Mater. Perform., 20 [8], 41 (1981).

5) G. J. Licina: Mater. Perform., 28 [10], 55 (1989).

6) 佐々木英次, 中原東郎, 神田幸雄, 大里一夫, 梅 野秀夫：防食技術, 26, 77 (1977).

7) W. Lee, Z. Lewandowski, S. Okabe and W. G. Characklis: CORROSION/92, NACE, Paper No. 190 (1992).

8) H. A. Videla, S. G. Gomez de Saravia and M. F. L. de Mele: CORROSION/92, NACE, Paper No. 189 (1992).
9）岡村 潔, 古山幸男, 梶山文夫: 第 39 回腐食防食 討論会講演集, 143 (1992).

10) J. Morales, P. Esparza, S. Gonzalez, R. Salvarezza and M. P. Arwvalo: Corros. Sci., 34 [9], 1531 (1993).

11) 宇城工：材料と環境，41，329 (1992).

12) M. Akashi: Bosyoku Gijyutu, 24, 31 (1975).

13) S. C. Dexter and G. Y. Gao: Corrosion, 44, 717 (1988).

14) R. Holthe, E. Bardal and P. O. Gartland: CORROSION/88, NACE, Paper No. 393 (1988).

15) S. Motoda, Y. Suzuki, T. Shinohara and S. Tsujikawa: Corros. Sci., 31, 515 (1990).

16) P. J. B. Scott and M. Davies: CORROSION/89, Paper NO. 186 (1989).

17) V. Scotto, R. di Cintio and G. Marcenaro: Corros. Sci., 25 [3], 185 (1985).

18）明石正垣：防食技術，32， 239 (1983).

19) B. A. Shaw, P. J. Moran, and P. O. Gartlands: Corros. Sci., 32 [7], 707 (1991).

20）元田傎一，鉿木場之助，石原靖子，辻川茂男 : 第 100 回腐食防食シンポジウム, 7 (1994).

21）高野道典，服部 勉：材料と環境，41，619 (1992).

22) F. Mansfeld and B. Little: Corros. Sci., 32 [3], 247 (1991).

23）天谷 尚, 幸 英昭：第 39 回窟食防食討踰会講演 集, 147 (1992).

24) S. C. Dexter and H-J. Zhang: Proc. 11 th Intl. Corrosion Cong., 4. 333 (1990).

25）佐々木英次：第 100 回窝食防食シンポジウム, 71 (1994).

26）石原靖子, 辻川茂男, 元田慎一：第 40 回腐食防食 討論会講演集, 663 (1993).

27) P. Chandrasekaran and S. C. Dexter: Proc. 12 th Int. Corrosion Cong., 3696 (1993).

28）天谷 尚幸 英昭：日本金属学会詼，58 [7], 775 (1994).

29）天谷 尚 幸 英昭：材料と㻴境，44［2]，94 (1995)

30) S. W. Borenstein: CORROSION/88, NACE, Paper No. 78 (1988).

31）菊他 靖, 松田福久：日本金属学会会報，32 [6], 393 (1993).

32) D. Walsh, D. Pope, M. Danford and T. Huff: JOM, 45 [9], 22 (1993). 